\title{
Depressurization Accident Analyses for the Fort St. Vrain Reactor
}

\author{
D. D. Paul
}

\section{MASTFR}

\section{Prepared for the}

U.S. Nuclear Regulatory Cominission

Office of Nuc!ear Reactor Pegulation

Under Interagency Agreement ERDA No. 40-545-75

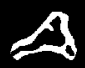

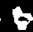

2

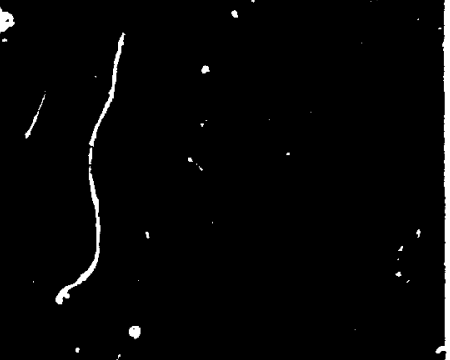



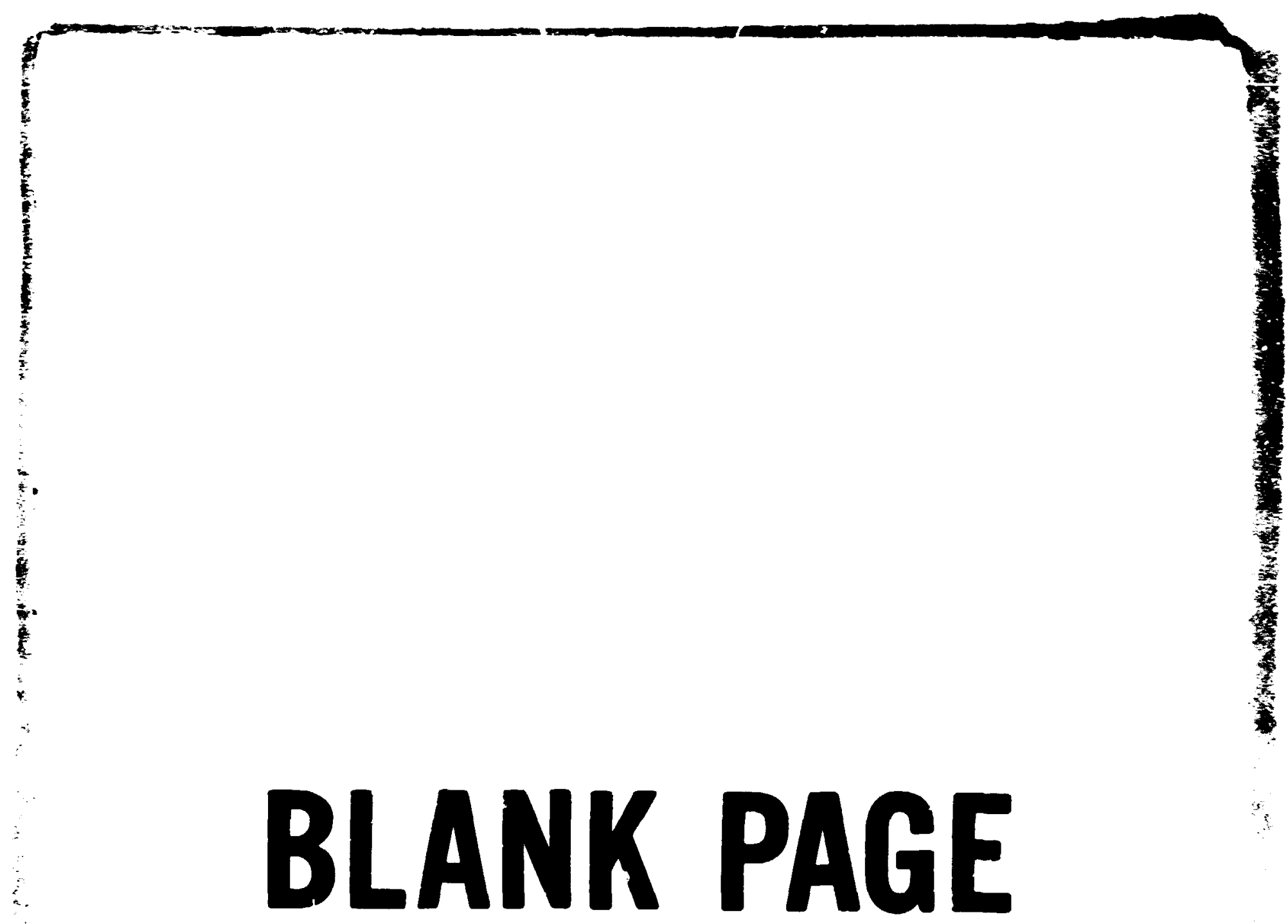

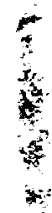

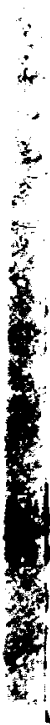




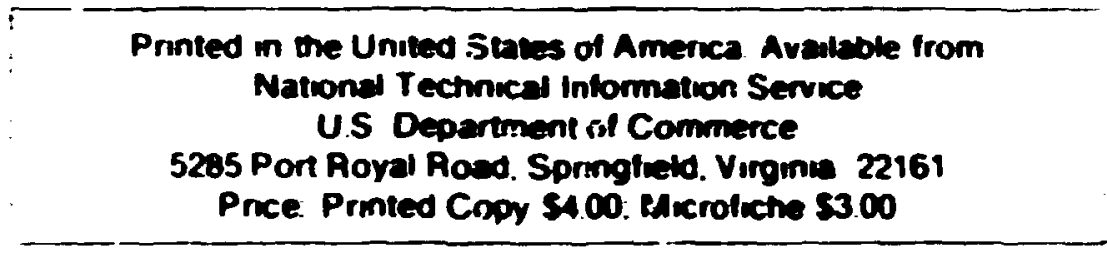

\footnotetext{
Tris report was prepared as an account of worn spaisoned by the Urind Stetes

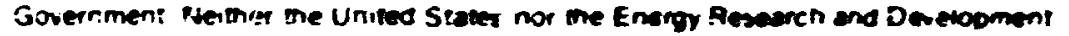
Aoministration Uniled States Nuclear Repulatory Commesion act ony of meit emoluyees nat any of meit contractors sencontractors or meir employens reates

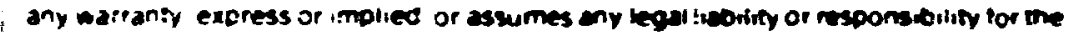
accuracy completeress or usefulness of any intormation coparatus product or

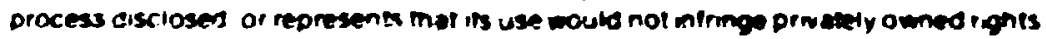




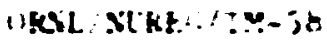

Conerace sio. Hi-7605-ene $2 t$

Enei-salng Iechnolog Divisiu:

DEPRESSTIRIZATIOS ACC:DERT NKALYSES FOR

THE FOAT ST. VRAix REACTOR

D. D. Paul

Mnuscript Completed - November 19. 1976

Dace Published -- Deccuber 1976

POTICE: This documed rontalns information of a preliainaty

nature. It is subject 10 revision or correction and there-

fore does rot represene a final report.

Prepared for the

U.S. Nuclear Regulatory Comisuion

Office of Suclear Reactor Regulation

l'nder Interagency distecment Eaph so. 40-565-75

Prepared by the

ONX RIDCE MATIONAL LNORATORY

Oak RIdge. Tennessee 37830

operated by

UzION CARAIDE CORPORAzION

tor the

ENERCY RESEARCH AND DEVELOPAENT ADMIMISTMAION 
comrerts

\section{Pare}

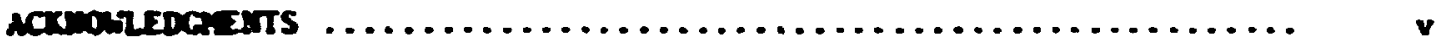

ansthnct $\ldots \ldots \ldots \ldots \ldots \ldots \ldots \ldots \ldots \ldots \ldots \ldots \ldots \ldots \ldots \ldots \ldots \ldots \ldots \ldots \ldots \ldots \ldots \ldots \ldots$

Immodrction $\ldots \ldots \ldots \ldots \ldots \ldots \ldots \ldots \ldots \ldots \ldots \ldots \ldots \ldots \ldots \ldots \ldots \ldots \ldots \ldots \ldots \ldots \ldots \ldots$

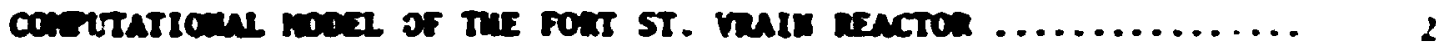

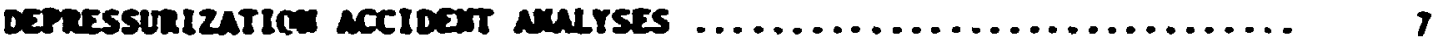

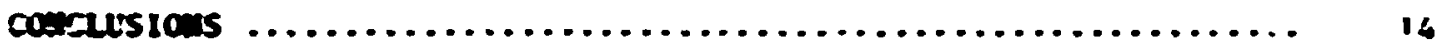

nerences $\ldots \ldots \ldots \ldots \ldots \ldots \ldots \ldots \ldots \ldots \ldots \ldots \ldots \ldots \ldots \ldots \ldots \ldots \ldots \ldots \ldots \ldots \ldots \ldots \ldots$

$-\infty+\infty+\infty$ 
ACKNOALELENTS

I gratefully acknowledge Dr. J. P. Sanders for tis guidance and eaccuragenent throuphout all phases of this work.

This work was perfornec as part of the work supperted by the

Diriston of Systens Safety, Office of suclear Rearcor äegulation, C.S. Suclear Regulatory Comisston. 


\section{DEPRESS:RL LAILA ACCIUEXT AHRiTSES FUR \\ THE FORT ST. YRAIS MEACTOP.}

D. D. Paul

\section{AASTRAC7}

Design-basis depressurizaclor accident analyses ior the Fort St. Vrain reactor were perforned using the FLODIS (Rei. $\rightarrow$ ) code- The FLOIS code rodels the active core, side reflector. gas anaulus between the core barrel and the PCRY liner. and the PCRV cooling syste. Results arc presented for the Pelion circulators operacing ar 10,550, 8800, and 700C rpa. Iaximur temperatures of selected components are olccted as a function of tene duriag the transient. Mone of the components studied exceeded the temperature at wich failure or damage may occur. However. there wust be sufficient nixing of the out let gas in tbe lower pleau to insure the incegrity of the steel liners of the stea senerator inlet ducts.

Kerwords: conduction, convection, orifice. Pelion circulacor, plenu, refueling region, reflector, cransient.

\section{ISTRODECTION}

During scartup testing of the fort St. Yrain reactor, cracks were discovered in the corvic coupling and bucket areas of the Pelcon c::culators. The circulators were replas:d. An investigat ion into the causes of che cracks revealed that the fiab!en could be eliminaced by operating the Pelccn circulators at a reduced speed. Since these circulators are used only during auxiliary cooling situations, a review oi postulated accidents that require their operation was performed. It was concluded that the ase serlous accident requiring use of the Pelton circulators was the design-basis depressurization accident (DBDA). The Ruclear Regulatory Comission (NRC) asked Oak Ridge Nat Ional Luboratory (ONVL) to provide an independent review of this accident.

For a DBOA, the following postulated events are assumed. The reactor is operating at $105 \%$ power. Instantoneously, the reactor depressurlzes to atnospheric pressure and sinultaneously the reactor is shutdown. There Is a five ainute delay in the startup of the Pelton circulators and then cooling is resued. The entre transient lasts for approsimately 10 hours. 

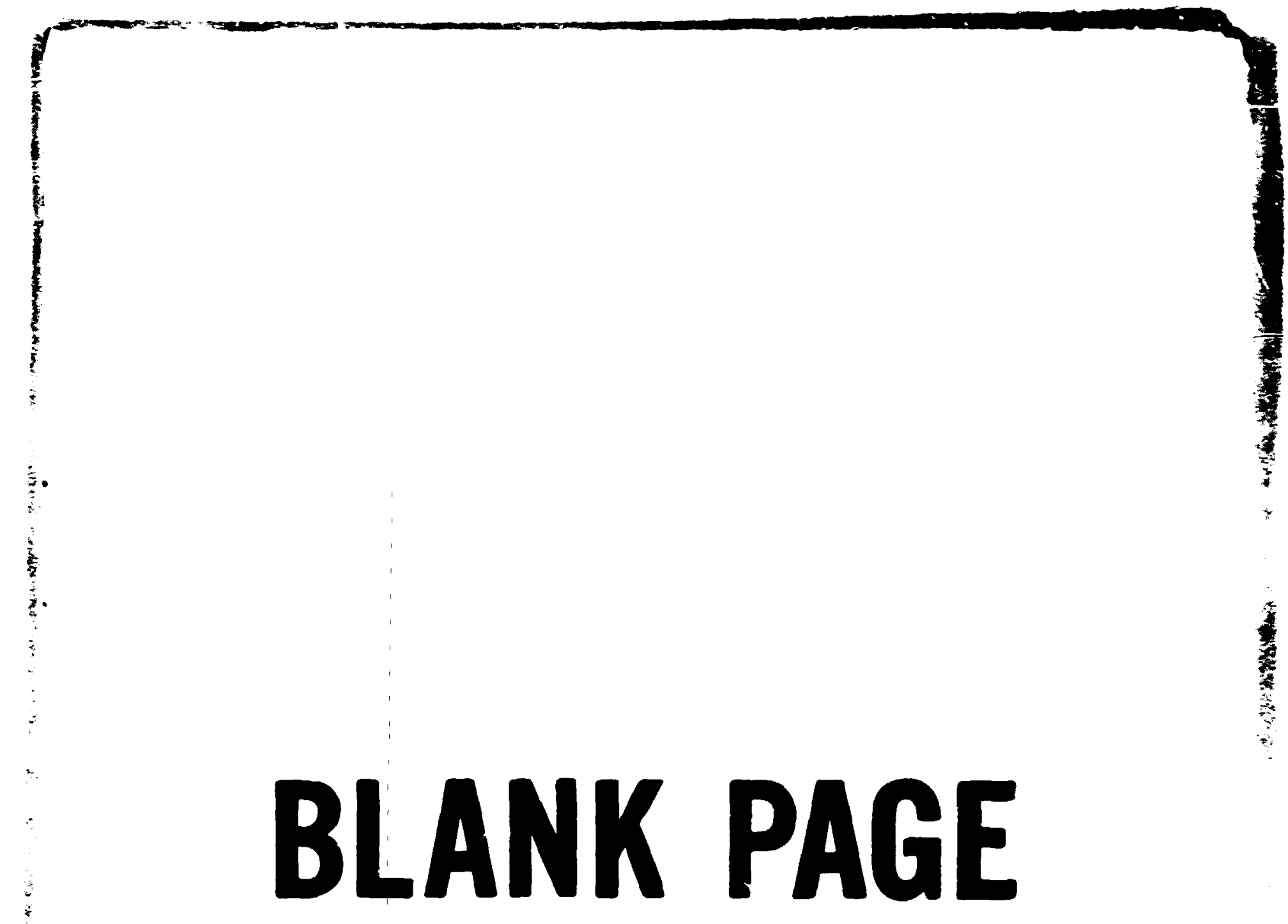


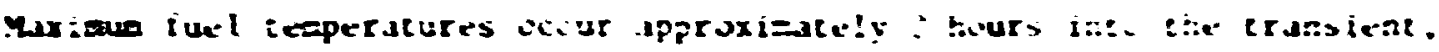

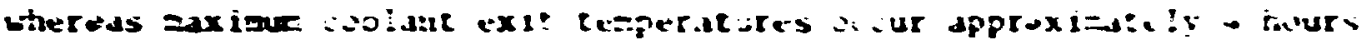

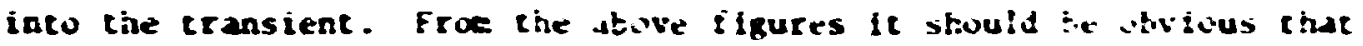
the response of the eatire syste reactor types undergoing postulated eccidents requirina =erker: core cooling. This is a =ajor safers advantage for HTiRs.

COAPITATIOAdL SODEL OF THE FOR: SI . IRA:S REACTOR

The FLODis iude was wielen specifically for andyzing the fort St. Vrain reactor. The acdel includes the active core. side teflector, gas annulus between $t^{2} z$ sote bartel and the PCRV IInet, the PCRT iwolinx system. cop plenu. bozoo plenum, and orifice cerizes. Essentially. the zode! Includes the upper sali if the PCRV abuve the core support floor as show in Fig. 1.

The FLUDIS cide calculates the ilow distribution weong tie 37 re: iselIng regions $u \bar{t}$ the Sort Sc. Train reactor. Furtheraute, the code lallilates, based on the sesh spacing, how the flow will distribute tithin it refueling region. There is an iaportant distinctsen to be ase hete. Intra-regional distribution of coolant flow is not handied by any other codes which model multiregion HTGR cores. Both naturai and forced cunvection flow ate awomodated with the FLODIS calculation.

The ceaperacure distribution is calculated throughote the entire reactor core. Heat is allowed to flow jetween all adjacent grid spaces: the encire core temperature distribution is calculated as a three dimenstonal heac transfer problem. Heat wy flow from the accive core. through the stde reflector blocks, ix.y be transported to the gas flowing within the anaslus between the core harrel and PCRV 1 iner, and may be conducted co the PCRV cooling system. Overall, the problem is a very complicated heat transfer - iluid flow calculation.

A unique feature of the floris code is that it adels the entire system with d rectangular grid as shown in Fig. 2. A typical refupling region is represented by 4 rectangular mesh spaces; whereas a partial refueling region is represented by 3 rectangular mesh spaces. There are 


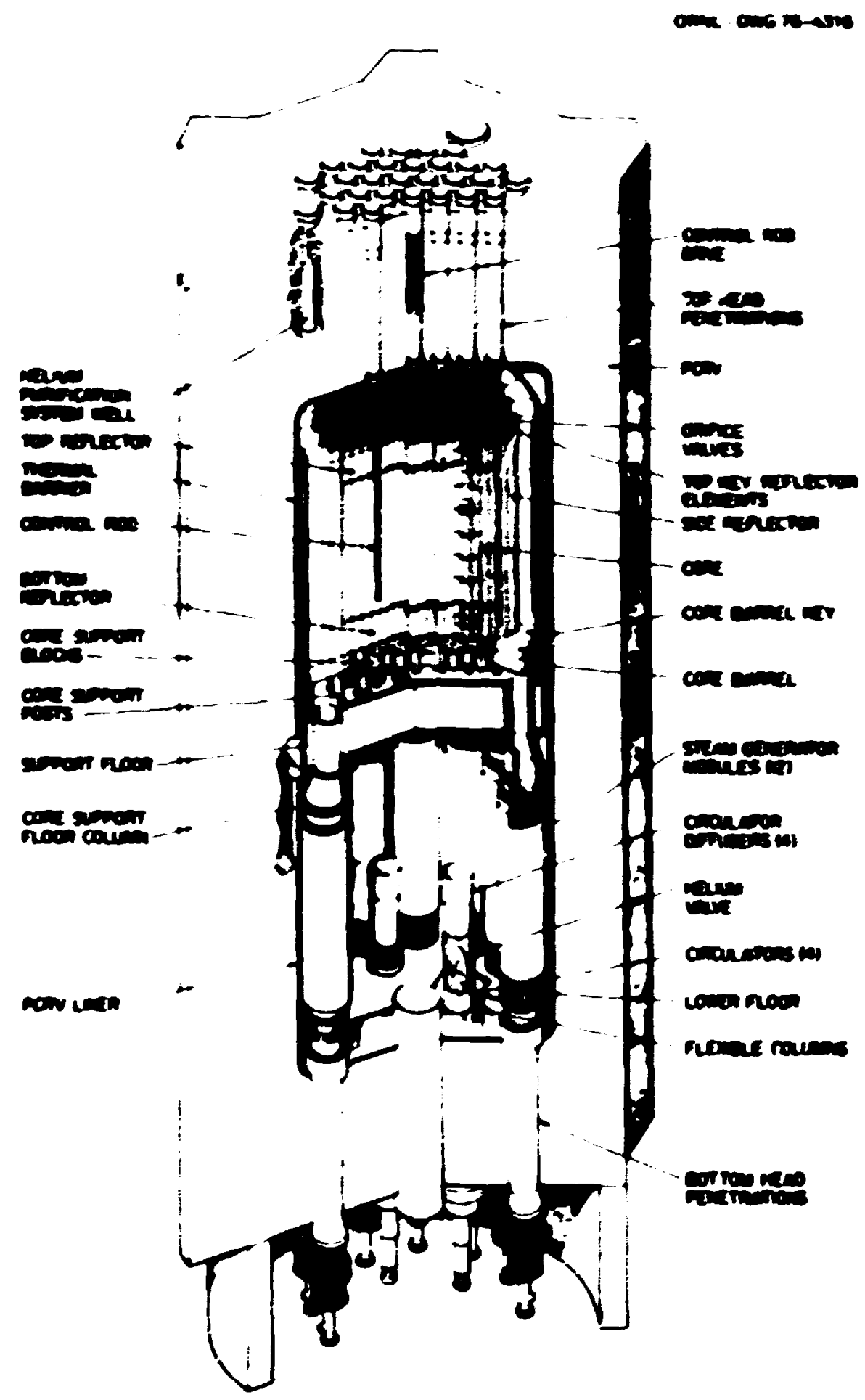

F18. 1. Reactor arrangeant. 


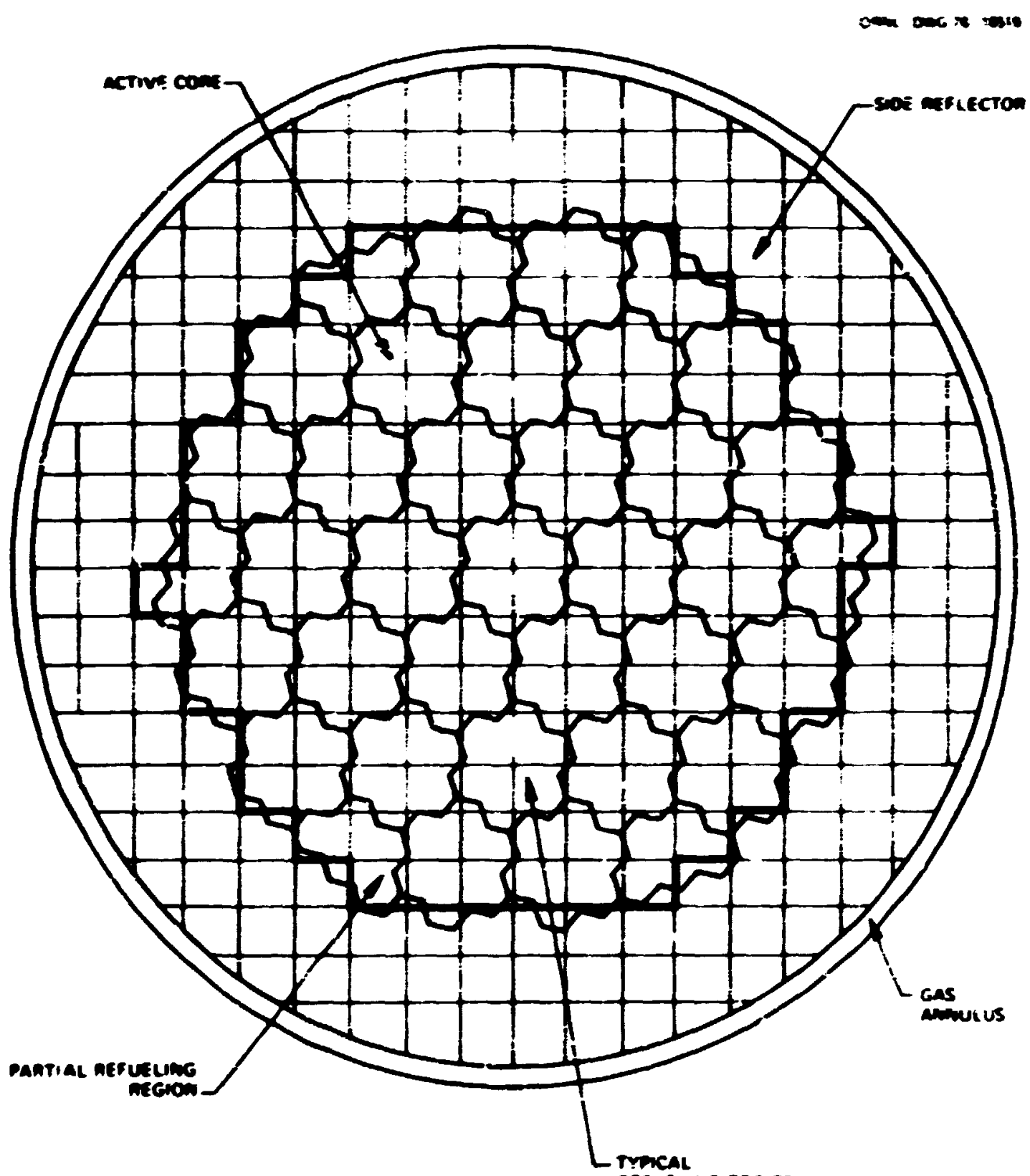

nefueling hesion

P18. 2. Wach epecing is roots code. 


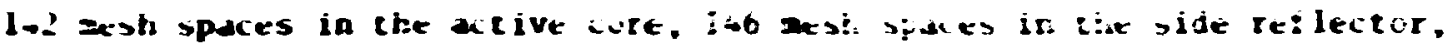

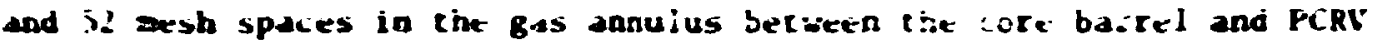
liber. suially tivere are 20 aesh spaces. rausting beth core and coojant audes. the extire syscet is representei by iz, ibl; nodes.

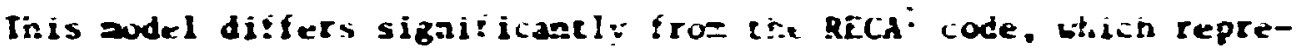
sents a refueling tegion b: a single hexaguna! desi spact. RECA uses

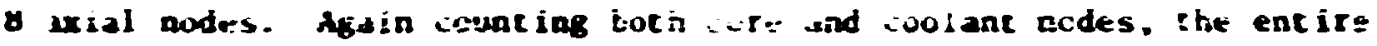
systea, as represented by RECh, uses apprixizate!y to0 ncjes. The rceal nuber of nodes used co represeac the sisten gives an indication of $t^{2}$ e comlexity of the anjysis, since buth the computer emery and tise requireants increase drasticali: win the nuber of nedes. This coeparijon illustrates tbe reiative size of the two i des.

a llow diagran of a typical seiueling region is shown in Fig. 3. For each of the 37 refurling regions, the flodis code calculates tine flow, $b$ : entering the otirice. Sowtset, the code goes one step further in that it now discributes the Ilow within a refueling region such chat $i_{i}=b_{1}+z_{j}+i_{3}+k_{0}$

Depending on the cemperature gradicnt across a re reling region, the subregion flows wy vary consideracly. For the DBuA analyses in this repert. as much as 2 isi difference in thow between subregions was observed. This result is ixportant beczuse the subrogion with the highest temerature will ottain the least ilut relative to the other subregions.

The orifice loss coeffic:uats are set based on biven steady-state requirements. Experimentai data obcained from General Atomic (Ref. 2) vere used to deternine ininum and maximu orifice loss coeficients together with orifice areas at steady-state conditions. Following depressurization and a reduction in conlant flow, the orifice loss coeificients are assumed to remain constant. Some experimental evidence exists for ocher types of orifices which indicate that this assumtion wight not be valid.: This is definitely one area where further experiental work should be done.

Twc limitations exist on the use of the FLODIS code. These are compucer memory and computer time restrictions. The FLODIS code needs $540 \mathrm{~K}$ of computer menry. For a DBDA analysis, the execution $t$ ime is 


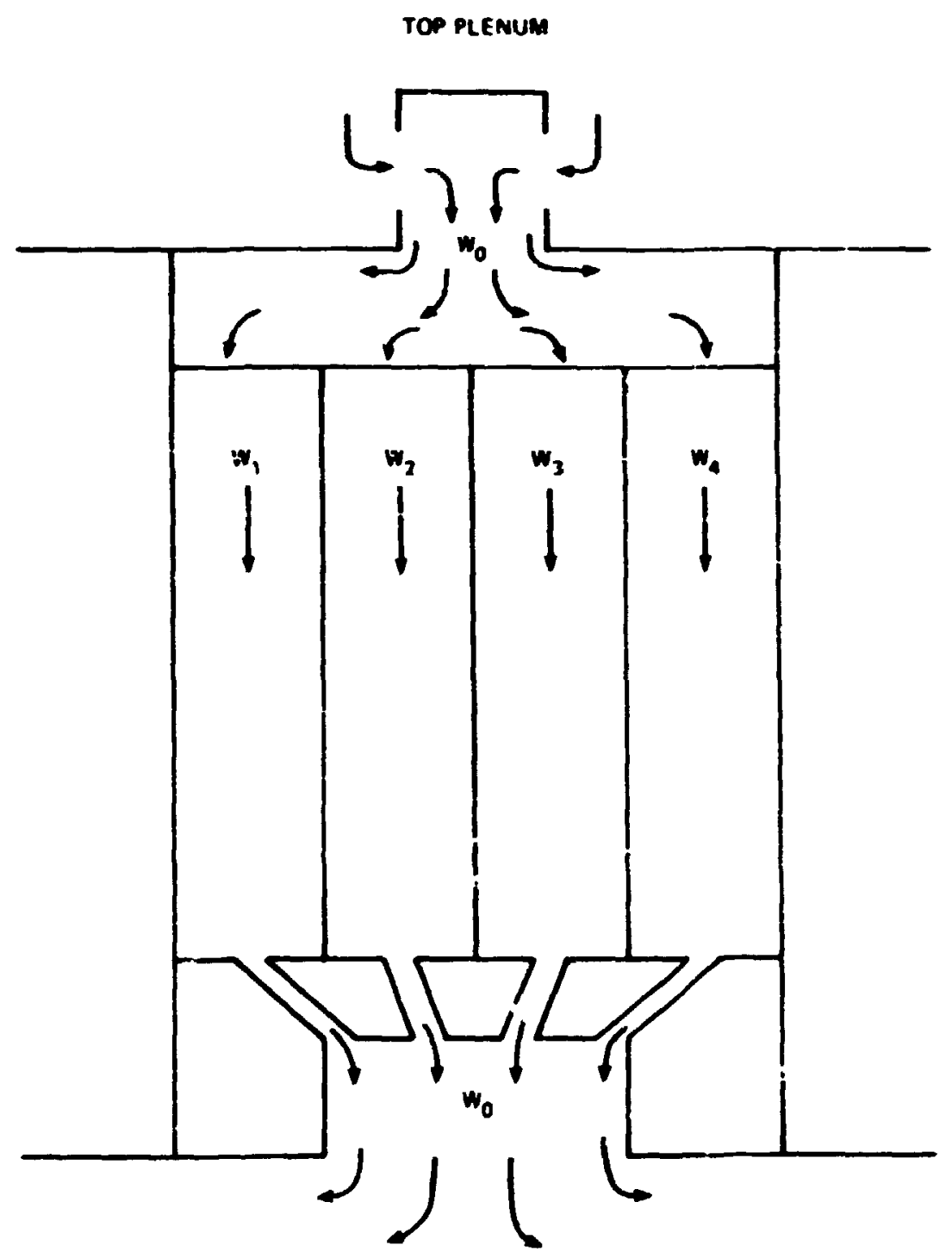

BOTTOM PLENUM

Fig. 3. Refueling region flow diagram. 
40 ainutes on the IBM $360 / 91$ computer at ORNL. Total cost for the job was \$110. However, the setup of a test case is not difficult because the code was written specifically for analyzing the Fort St. Vrain reactor. All of the input required to define the geometry of the reactor has been incorporated intercally in the code. This has allowed for detailed eodeling of the entire system, since general purpose routines need not be devised.

For detalls concerning the differential equation, ethod of solucion, and calculation of conductances as soived by FLDIS, docimentation of the zode has been ade in a previous report (Ref. 4).

\section{DEPRESSLPTTATIOA ACCIDETT NWLYSES}

Three separate cases of depressurization sccidents were analyzed. The only difference between the cases was the cholce of the circulation speed. General Atonic originally specified the Pelton circulator speed to be 10,440 rpm. During 1nspection prior to startup of the reactor, cracks were discovered in the curvic coupling and bucket areas of the Pelton c1rculators. The circulators were replaced and the high speed crip setting was reduced to $8800 \mathrm{rpa}$. To be conservative General Atontc analyzed the DBDA with a c1rculator speed of $7000 \mathrm{rpa}$. Analyses of the design-bagis depressurization accident at these three circulator speeds were performed. Values for the circulator total flow and gas temperature were supplied by General Atonic.

Figure 4 shows maximum iuel temperatures during the trassient for the three different ctrculator speeds. Also show on the graph is the cricical safety limit for fuel particles. Th1s ts the temperature above which there 18 a rapid deterioration of the fisston product barrier. The above analysis Indicates that the teeperatures are low enough so as to insure that the design criteris will not be exceeded.

F1gt re 5 shows the maximu coolant outlet temperature for the different circulator speeds. Conservatively, this temperature ma be taken as the local temperature of the cast s1llca blocks lining the floor of the lower plenum. Aguin there is an adequate safety argin between the curves and the critical safety 1 imit for cast allice blocks. The critical safety 


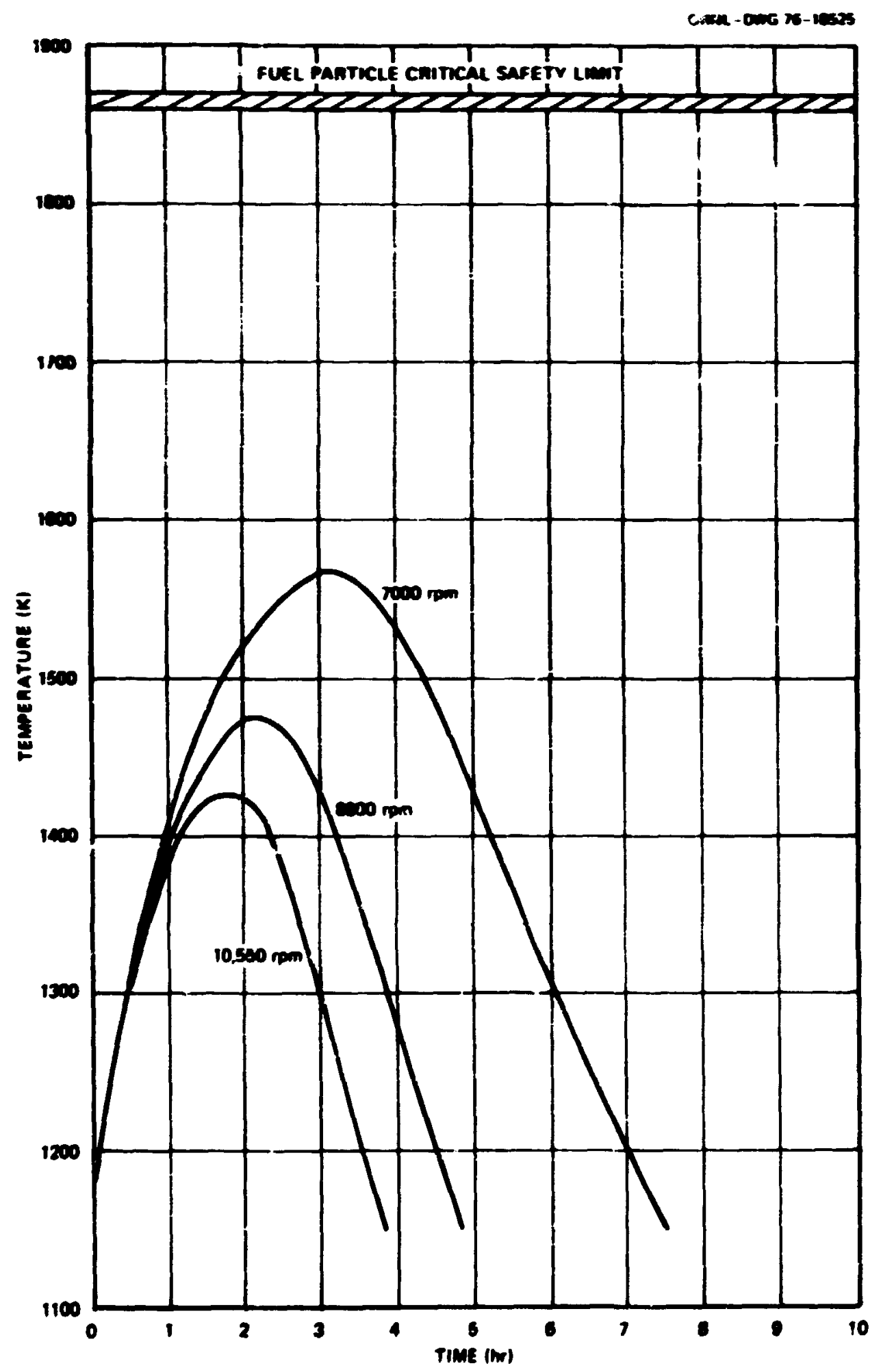

P18. 4. Maximu core tomeratuze during DBDA for selected circulat1on speeds. 


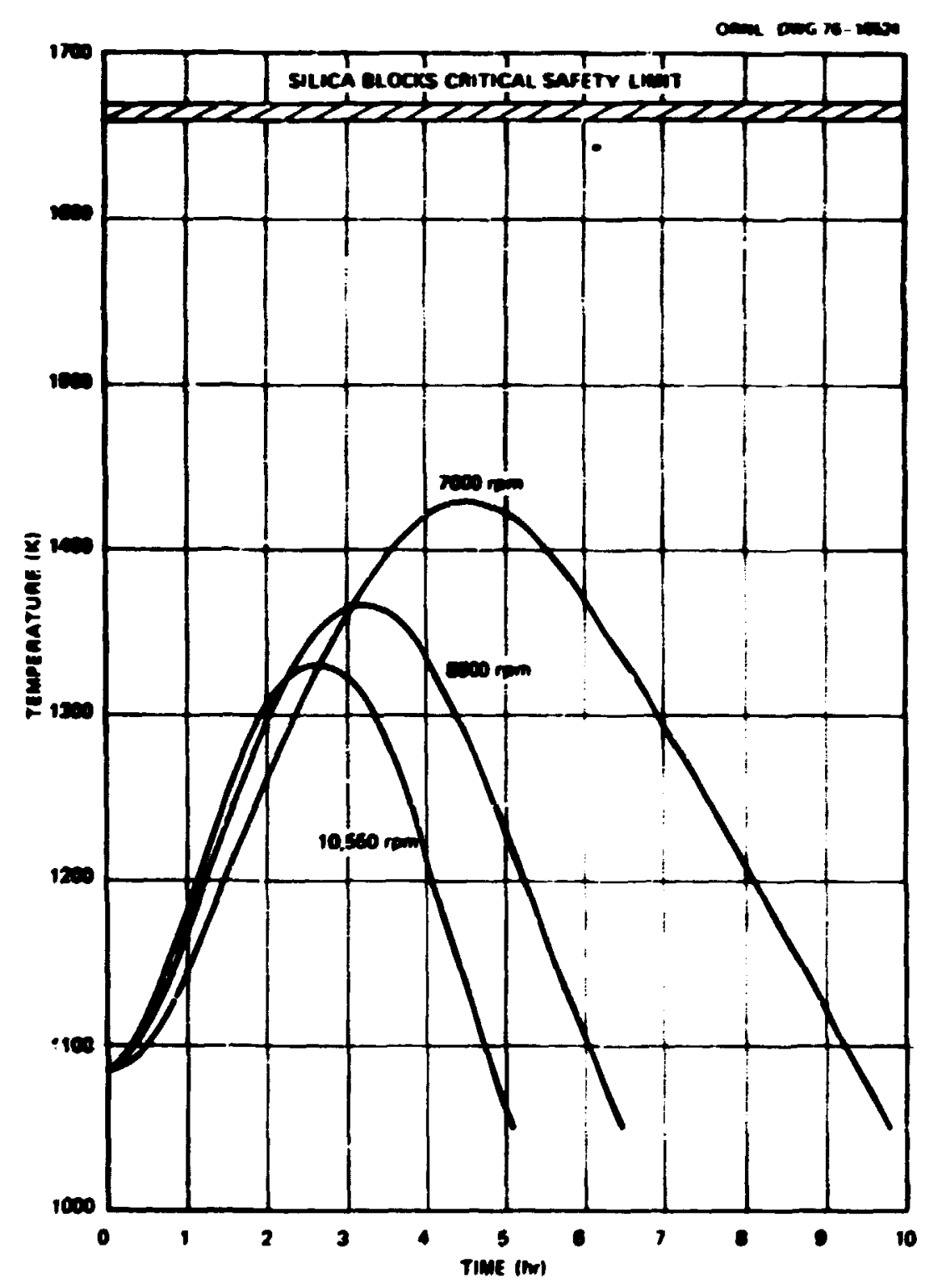

Fig. 5. Maximu coolent outlet temperature during a DBDA for selected circulator speede. 
linit for this componeat is the tesperature which causes creep deformation of 27 at the expected operating stress level in one hour.

Figure 6 shows the alxed mean temperature of the ccolant. The critical safety linit showa on this graph 1 for the ste.l liners on the steen generator Inlet ducts. Again, this is the temperature above which creep deforation of 27 occurs within the structural eleneats in one hour. Th1s plot shows that if the refueling region flowe aix thotoughly before eatering the ducts, there is an edequate safety angin for this component. However, It is Interesting to consider the case of inperfect axing. Aibough all experiental date ade by Ceneral Atonic on aixing in the lower plenus was obtalned at full flow simulations, It still provides insight into the physical processes. Data by W. E. Walkur (Ref. S) shows a aixing factor of 0.3 can be used for the Fort St. Vrain reactor under full flow conditions. The alxing factor, $\theta$, an be defined as,

$$
\theta=\frac{T_{D}-I_{H}}{T_{R}-I_{M}}
$$

where

$\theta=$ Dixing factor,

$T_{D}=\operatorname{axima}$ cemperature it ihe duct,

$T_{R}=$ axine temperature leaving refueling region,

$T_{M}=$ axed mean temperature.

Figure 7 shows the waximum temperatures in the stem generator inlet ducts for a range of aixing factors between 0.0 and 0.5 , and for the Pelton circulators operating at 7000 rpa. Hete that even with o alxing factor of 0.5 , the critical safety lintt 1 still not exceeded.

As an interesting sidelight, results from the DaDA at 7000 rpe are compared with those obtalned from General Atomic's RECA' code. Figure 8 shows the cosparisons for maxime fuel, axima coolant nutlet temperstures, and alxed-aean coolent outlet teaperstures. Some of the differences in the two adels can be Inferred from this graph. Note that the aximu temperature curves are Identical to sbout one hour in the transient. After this tine there are sufficient gredients between refueling reglons to reflect differences in inter-regional conduction wodeling. The reasons the flODIs temperatures peak higher than RECA temperatures are 


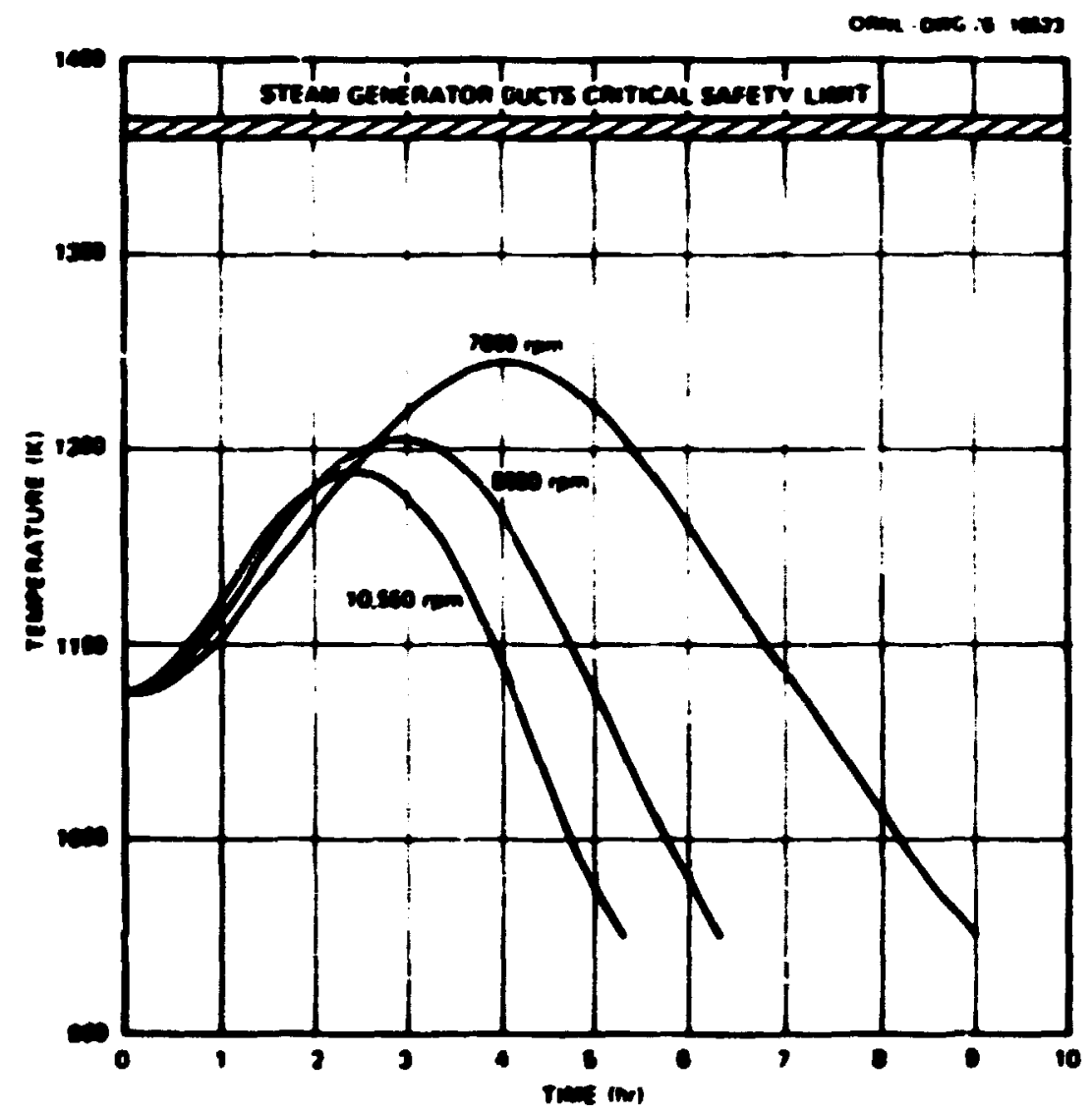

P18. 6. Hired enen coolent toperature durias a Dan for eelected circularor apede. 


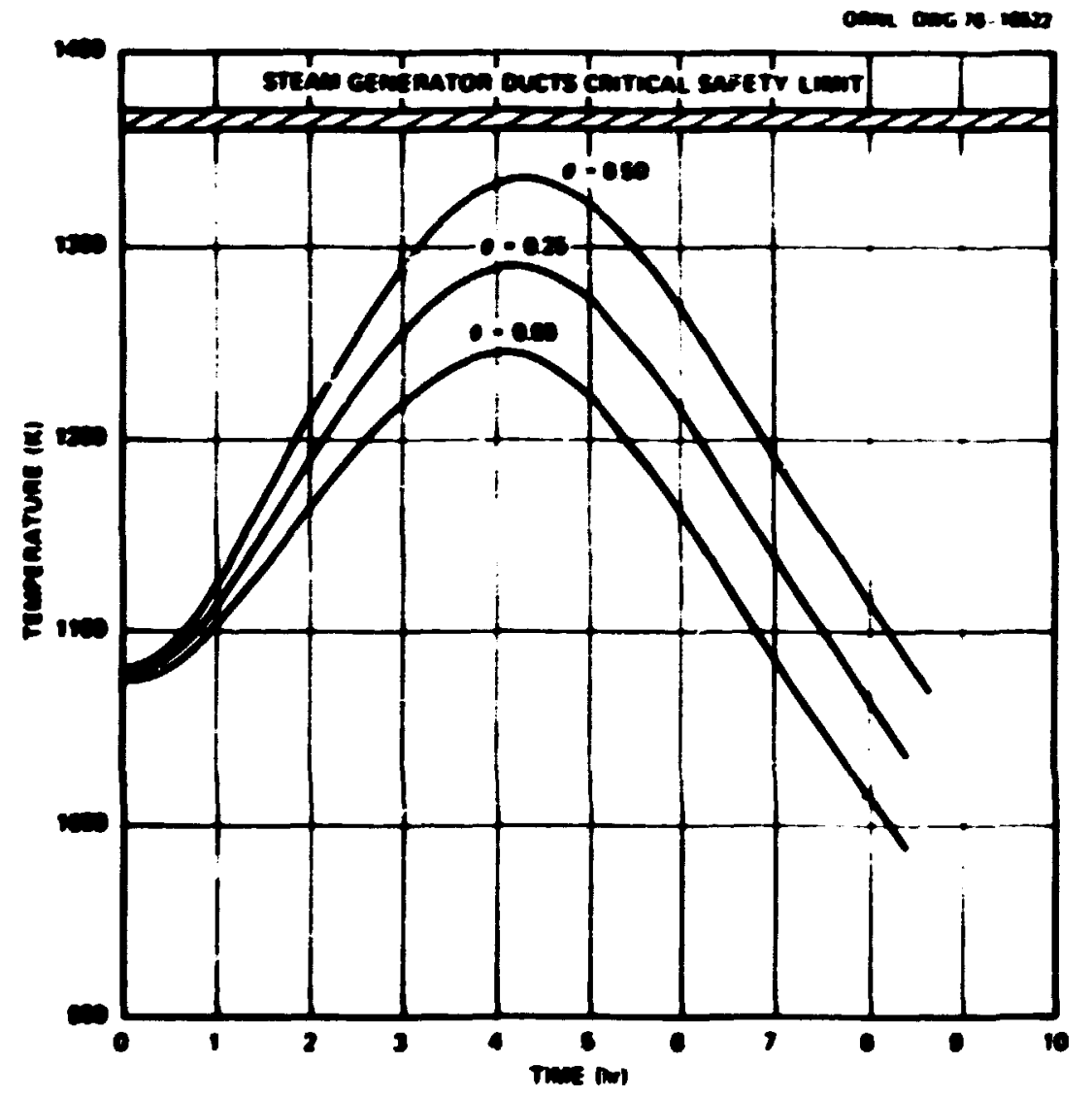

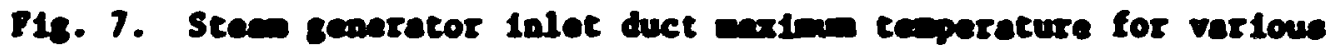
alxine factors. 


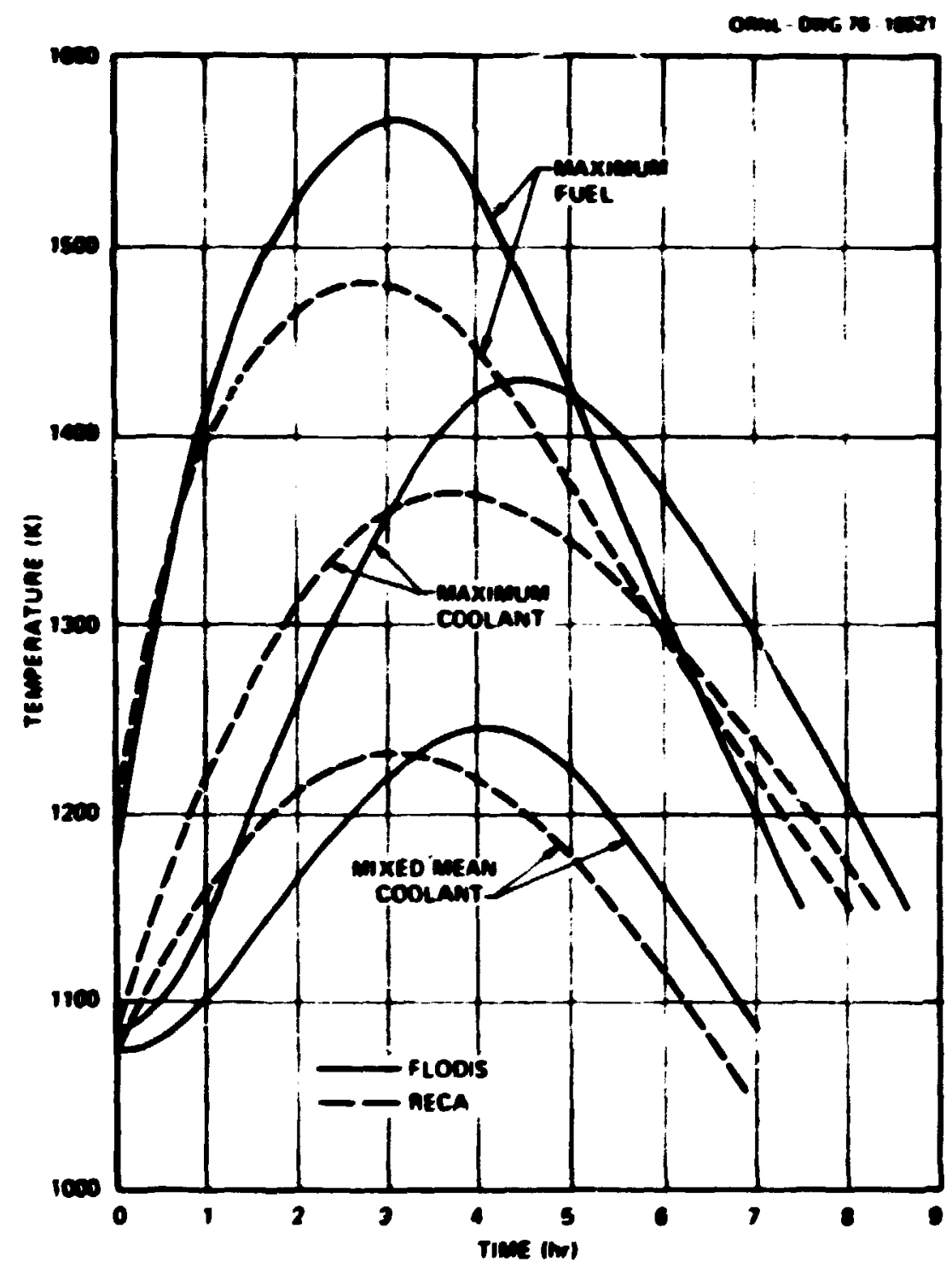

F18. 8. Comparicon of PLODIS and RECA temperature during DSDA with 7000 rpa circulator speed. 
due to: (1) the fine eseh spacing allow grotleats within a refueling resion to be deternined, and (2) the distribution of coolant vithin a refuellas region according to the finer meah ofdcing is more realistic of che actual phyoical process.

Wote also that the coolant temperature curves vary eigaificanty in shape early in the transtent. Two reasons extst to explain this phenomena. First, the two codes use ext:-ely different convective heat transport codels. FooIs ises the exponential approach sethod (Ref. 4) wheress nxca uses the endpolnt weighting sethod (hef. 2). The exposent1al approach eacbod is valid froe a phyeical stadpulat ard is nunerically stable uoder all flow condiclons. The endpolne walghtiog method is nucericall., stable but does not have a physical beats. Secondly, the codeling of the core support block is probably the cause of the differeaces in shape of the curve at the outset of the tranatent. FoDIs has 2 nodes each for the botton reflector, upper level of the core support block, and lower level of the core support block for a cotal of 6 aodes. RECA lups the sace region into one node and therefore the coolant falls to see the axial teoperature gradient which develops in this region after accident initiation.

Finally, the curves of the atxed-anan outlet coolent temeratures give an Indication of the hat renoval process durins the transient. The areas under these cui-res are directly proportional to the heat rewoved from the entire reactor. RECA predicts considerably nore heat reaval earlier in the traneleat. This causes Rech fuel and coolant temperatures to peak at an earlier tine than the correaponding noDis curves.

\section{conclusions}

Results predicted by the FLODIS code for a DAD show that the reaponse of the syaten is such that the reactor and comonents matatain their integrity throughout the transieat. In codeling the sycten two areas were nuted where additional work could is done. At low flow the orifice lose coefficlents have not been verifled, and the alxing of outlet gas etrease in the locmer plonum has not been studied. Both of these 
uacertainties are important for predicting the overall response of the Bort 5t. Vrain reactor core. 


\section{REFERENCES}

1. H. H. Chi and C. J. Malek, Description of the Reactor Dnergency Cooling Analysio Code, RECA, GA-10273 (August 1970).

2. J. P. Sanders, "Information Obtained fron GaC on Safecy Analysis of HTGR.," Letcer (June 1976).

3. W. Mclabe and J. Saith, Lnit Operations of Chemical Engineering, Pp. 449-452, McGraw-H111, 1956.

4. D. D. Paul. FLODIS: A Computer Mociel to Determine the Flow Distribution and Thermal Response of the fort St. Urain Reactor, Oxul/ni-5365 (June 1976).

5. H. E. Halker, PSC Region I Fiou Model (Semes 2) Test Report, GND-8625 (July 8, 1965). 